\title{
Polish discourses concerning the Spanish Civil War. Analysis of the Polish press 1936-2015
}

\author{
प⿴囗十口 \\ Wojciech Opioła \\ UNIVERSITY OF OPOLE, POLAND
}

DOI: $10.19195 / 1899-5101.10 .2(19) .4$

\begin{abstract}
The Spanish Civil War of 1936-1939, as an ideologised and mythologised event, has been and is still used instrumentally within the Polish public discourse. The war was an important subject for the Polish press in the years 1936-1939. The Catholic, national-democratic, and conservative press supported General Franco's rebellion. The governmental and pro-government press also supported the rebels. The Christian-democratic and peasants' party press remained neutral. The social democratic, communist, and radical press backed the Spanish Republic - as did liberal-conservative organs such as Wiadomości Literackie. After the Second World War, the Polish communist media created the positive legend of Polish participants in the Spanish Civil War in the International Brigades, labelling Franco's post-war regime fascist. In contemporary Poland, the same division within the Polish political scene as in 1936-1939 can be observed. Starting in 1990, the Spanish Civil War, as a subject of the Polish political discourse, has been the source of heated disputes, whose participants often present more radical views and narratives. The key issues that entered the canon of Polish political disputes after 1989 (the International Brigades of volunteers, religious crimes, the support of fascists and communists for opposite sides of the conflict), are concentrated along the lines of the dispute arising from the debate within pre-war Poland: the clash of the traditional, Catholic world with the communist revolution.
\end{abstract}

KEYWORDS: International Brigades, political discourse in Poland, Polish political press, Spanish Civil War, collective memory.

\section{INTRODUCTION}

In the article I present the contemporary Polish discourses concerning the Spanish Civil War. The analysis is based on the data taken from Polish newspapers and journals. The scientific method for investigating are content analysis and discourse analysis. The article is organized into two sections. The first discusses the Polish discourse in the years 1936-1989. The second is a presentation of contemporary discourses concerning the war. Thus, the objective of the paper is, firstly, a comparative 
study of the public discourses from three periods (1936-1939; 1945-1989; 19902015), and secondly, a diagnosis of relations between these discourses and the political regimes in Poland: authoritarian, totalitarian, and transitional democratic. According to the area of discourse studies, I use the rhetorical perspective to the discourse analysis (DA), which is appropriate to study, when the statements are expressed "in the awareness of a differing or opposing view" (Leith \& Myerson, 1989, p. 2). Then the analysis of speakers, sources of information, language, is understood as a symbolic power rivalry (Bourdieu \& Thompson, 1991). In this context I understand the discourse as the political phenomenon, because it reproduces the social order and is the tool of political control.

The Spanish Civil War, which in this article serves as the subject matter for research on political instrumentalization, was a consequence of the political conflict of 'two Spains': the traditional, Catholic, and conservative one, and the liberal, leftist, democratic, and republican one (Beevor, 2009; Gola, 1995; Jackson, 1999; Preston, 2012; Thomas, 1995), provoking an internal military conflict. Both sides of the conflict quickly won international support, both military and rather less calculable, spiritual, as well as a feeling of solidarity with those who fought. The media's reaction was mixed, ranging from impartiality in informing readers about the situation on the battlefront, to politically committed articles containing various forms of propaganda. Such developments also occurred in Poland, both at the time of the war (1936-1939), later, and even until the present day (Bednarczuk, 2008; Glondys, 2014; Kieniewicz, 2001; Maciejewski, 1998; Opioła, 2013, p. 73-82; 2016; Sawicki, 2008).

Creating a 'non-real' sequence of events was not the initiative of Polish political journalists at all. During the Spanish Civil War, political propaganda was deliberately used by both sides of the conflict, as well as by their allies - the USSR, the Third Reich, Italy, and the Communist International (Southworth, 1977; 2002). Pieces of information that reached Poland were already biased in accordance with the author's point of view.

This raises the research question: why, in present-day Poland, do different groups care about manipulating the history of the Spanish Civil War? There might be many motives and reasons. The war still stirs up strong political myths, which are easily used to advocate radical ideas, based largely on appeals to emotion. Myths are based on beliefs, not facts, which enables the creation of irrational ideas, imposed by a group, but based on authority (Barthes, 1970, p. 31; Eliade, 1999, p. 15-16). The main research problem of the article is the question of contemporary Polish collective memories and discourses concerning the Spanish Civil War and the politics of memory. In addition, the history of the Spanish Civil War blends with the general current of the politics of memory in Poland and the review of the former political system's past. The attention of anthropologists, sociologists, and historians has been drawn to a very significant surge of interest in historical remembrance within the last 25 years, resulting in the creation of an "era of remembrance and commemoration" (Francois, 2010, p. 18-19). This new era differs from past ones in that the truth 
is no longer at the centre of historical research, but rather 'fairness' seen according to current ethical standards. These are never final, but always negotiable, because they evolve together with social changes (Szpociński, 2010, p. 16). The second area of investigation will be the analysis of the mentioned three periods, to determine whether contemporary Polish discourses concerning the Spanish Civil War are the continuation of past debates, or have new political elites in the democratic Poland established new historical narratives?

\section{POLISH DISCOURSES BETWEEN 1936-1939}

The last three years of the Second Polish Republic was the time when the Spanish Civil War took place. For the Polish press, the war was among the most important subjects. In the first stages of the war (July-October 1936), it took the covers of many newspapers of different political provenance, and from this period comes the majority of press citations. Despite the growing institutionalization of the authoritarian regime in Poland, the journalistic discussion that touched upon the Spanish Civil War was quite welcome by the censorship authorities. Poland at that time had a new political situation, after the adoption of the April Constitution, Józef Piłsudski's death in 1935, and the consolidation of an authoritarian government. It was also a time of the development of major ideologies, which greatly influenced the practice and doctrine of Polish political groups, the intensification of anti-Semitism, and labour strikes and rallies (Hertz, 2003; Friszke, 1989).

The political situation in Europe and Poland at the time made the Spanish Civil War an important subject, and such was the way it was treated (Judt, 2008a, p. $613 ; 2008$ b, p. $293 ; 2011$, p. 50). The war, seen by the majority of newspapers as the confrontation between fascism and communism, was often an excuse for political attacks, analogies with the political situation in Poland. Media scholars believe the press campaign concerning the Spanish Civil War was one of the most interesting journalistic disputes in the Second Polish Republic (Ajzner, 1968; Cieński, 1990; Habielski, 2009; Nałęcz, 1993).

Within the first months of fighting, a number of Polish journalists went to Spain. The most valuable articles, both in literary and factual terms, were regarded as those by Ksawery Pruszyński, a correspondent with Wiadomości Literackie, Roman Fajans (Kurier Warszawski), and Jędrzej Giertych (Kurier Poznański). Their reportages were also later published as books (Fajans, 1937; Giertych, 1937; Pruszyński, 1937). The ones by Pruszyński were nominated for the best Polish book of 1937 (Sprawozdanie..., 1938). The political affiliation of the reporters was totally different from one another, yet they became experts on the war, and it was common to polemicize with them and, at the same time, quote from them. Apart from those mentioned above, there were another nine war reporters in Spain during the Civil War (Czajka, 1980, p. 255-256). 
The Catholic press had the largest circulation in Poland in the 1930s, and information provided by this press was rather schematic. There were three forms of sourcing information: dispatches from battlefields, commentaries touching upon the war in different ways, and testimonies of Catholics' martyrdom. One characteristic feature of the Catholic press was presenting the situation at the Spanish Civil War battlefront on the basis of the dichotomy good-bad, they-us (Macała, 1997, p. 124; Opioła, 2010a, p. 369-370; 2010b, p. 8). Right-wing parties were called 'national Spanish army', 'the defenders of faith', and 'General Franco's military movement'. The republican side was dubbed 'communists', 'reds', and 'Bolshevik hordes' (Bednarczuk, 2008, p. 125-133). Due to the actions of the Catholic press, epithets such as 'freemason', 'Jew', and 'communist' became, in the context of the war, synonyms. For catholic journalists, the significance of what was going on in Spain did not allow for impartiality; even more than that, it was demanded to distinctly stand on one side of the conflict or the other. The bishops wanted people to present such an attitude: "nothing more is left for mankind and the nations than to choose between Christianity and Satanism, speaking today through communism and atheism" (W chwili..., 1936).

The government and conservative press (the conservatives at this time backed the Polish government's policies) tried to show the Spanish Civil War objectively, although there were also cases of pro-Franco pieces of journalism in editorials. The policies of the Polish government constituted a set of incitements for covering the war this way. At League of Nations meetings, Foreign Minister Józef Beck and Ambassador Tytus Komarnicki indirectly backed Italy and the Third Reich through acting against the USSR's actions aimed at introducing a ban on the Axis countries' intervention in Spain (Maciejewski, 1998, p. 275). Conservative press journalism was traditionally anti-communist. It saw a dangerous game in the war in Spain, which should be won by the national side; otherwise "Italy and Germany will do anything in their power not to allow the communist revolution to last in Spain" (Ponure cienie..., 1937).

Polish National Democracy's (ND) attitude towards the Spanish Civil War was original, stemming from a different way of understanding leadership. ND, as a nationalist movement often emphasising its own anti-fascist stance, had reservations concerning any form of personality cult (Kotowski, 2006, p. 217-218). Thus, the press did not have a one-sided view of General Franco, who was glorified by both the conservatives and Catholic press. ND rejected totalitarianism as a possible form of government to introduce in Poland. A materialistic worldview and cult of violence with a lack of respect towards human dignity were the factors that kept ND away from such ideas (Komarnicki, 1937; Wasiutyński, 1936). Among groups that backed Franco's 'crusade', ND respected the Carlist Movement, and the quasi-fascist Falange was treated with reserve, if not total rejection. As Jędrzej Giertych wrote: "Falange Española - this is Spanish fascism (...) this is a reverse Marxism (...) how easy the socialist masses could transform into fascist ones" (Giertych, 1937, 
p. 331-332). Despite these doctrinal reservations, as well as typically anti-German attitude, the majority of ND journalists accepted the necessity of Italian and German intervention in Spain. This help was seen as effective strength in the struggle against communism (Bartoszewicz, 1937; Maciejewski, 1998, p. 280). Wojciech Wasiutyński made a remark that "for Spain this war is a blessing (...). The communist anti-religion woke Spain up. It forced Spain to dig out the one thing that was precious within the nation, however deformed and gilded with gold just like baroque statues - Catholicism. The very fact that the people of Spain have something to die for is priceless for the country" (Wasiutyński, 1936).

On the other side of this journalistic battle was the press of the so-called democratic group, as well as press organs of the radical left. The democratic group was a conglomerate of political opposition parties, which were bound only by opposition towards power aiming at introducing an authoritarian regime. There were political parties and their press organs - both conservative-liberal groups (such as Wiadomości Literackie, Polonia), socialists (Robotnik, Czarno na Białem) and peoples' parties (Zielony Sztandar, Piast, Gazeta Grudziadzka). The democratic press' attitude towards the war was deeply diversified, beginning with neutral waiting or criticising the war, to supporting the Spanish Republic. Antoni Słonimski one of the most engaged journalists in the political campaign against anti-Semitism and fascism in Poland - often commented on what was happening on the other side of the Pyrenees (Słonimski, 1936a; 1936b). The leader of the Christian democrats, Wojciech Korfanty, despite being a declared anti-communist, criticised actions carried out by General Franco's people (Korfanty, 1936). The Wiadomości Literackie reporter in Spain was Ksawery Pruszyński, a conservative journalist. His reports from war-torn Spain in 1936 and 1937 were met with a lot of replies and comments. According to some of them, he moved from a conservative, traditional position to the left wing. Indeed, his first reports comprised reflections proving that he had been experiencing something new. "This fight goes much wider: it hides away more promises and threats for them, who will wind up inside of it" (Pruszyński, 1936).

The official press organ of the socialists - Robotnik (The Worker) - was actively engaged on the side of the Spanish Republic. This newspaper's journalism was dominated by emphasising the class character of the Spanish conflict and believing in an international, fascist conspiracy (Niedziałkowski, 1936). It stressed that the rebellion was against legal authority and started to defend the interests of the bourgeoisie that was not ready to take the loss of privileges easily (Boski, 1936).

The radical left's press was instrumental in promoting help and solidarity with the republican government in Spain. For the communists, one characteristic feature was that the subject matter of any articles published in the communist press (Czerwony Sztandar, Dziennik Popularny) was pre-imposed by the Political Bureau of the Polish Communist Party (Komunistyczna Partia Polski, KPP), which could not allow any polemical texts to be published. They helped Spain by raising money and illegally recruiting volunteers for the International Brigades, through 
which there were a few hundred volunteers from Poland who made it to Spain. But there were 4,000 Polish soldiers fighting as volunteers for the republicans, although the majority of them - farmers and miners from the north of France and Belgium - came to Spain without the consent of the KPP (see for example Bron, 1967, p. 229; Toruńczyk, 1965, p. 185-187). The propaganda effort of the communist press was targeted at Poles, in order to convince them that the power behind starting the war was international fascism (Górecki, 1936). The newspapers devoted a lot of space to stories told by the Polish volunteers fighting in Spain (Polscy robotnicy..., 1936).

\section{DISCOURSES IN THE PERIOD 1945-1989}

The discourse concerning the Spanish Civil War during 1945-1989 was marked mainly by the communist doctrine of the place of the media within the political system, which demanded the common ownership of mass media and its functioning on two basic features: journalists should be formal members of the Communist Party - conveyor belts between the party and the masses; and, mass media content is the extension of Marxism-Leninism. In fact, however, analysis of the language and character of political journalism between 1945-1989 points to times of hardened censorship intertwined with moments of thaw.

Propaganda's attitude towards the Spanish Civil War might be analysed through the engagement of the Dąbrowszczacy - Polish combatants of the war - into Polish political life after 1945. Up to 1947-1948, the number of combatants within the administration, army, and Communist Party increased, and then fell rapidly. The prestige of the Dąbrowszczacy at the beginning of the introduction of the communist regime stemmed from being well-prepared for political duty, as well as intelligence and military ones, together with the legend surrounding General Karol 'Walter' Świerczewski, the commander of the International Brigades and one of the highest party officials at the time, up to his death in 1947. During the Stalinist period (1949-1955), the Dąbrowszczacy were politically repressed, lawsuits were filed against them, and they lost their jobs. In 1956, with the emerging political thaw, came the process of rehabilitation of the Dąbrowszczacy. In the years that followed, their role became bigger and bigger, reaching its peak in the 1960s, which led to the communist legend of the Dąbrowszczacy being born - the soldiers of liberty, loyal to the ideas of communism. In the 1960s the Dąbrowszczacy were indulged both economically and ideologically (Cieński, 1990, p. 32).

The cult of the Dąbrowszczacy was an important part of the propaganda image of the Spanish Civil War. The picture of the Spanish Civil War, created according to Marxism-Leninism, included the following censorship directives:

- after the People's Front won the 1936 February election to the Spanish Cortes Generales, Italy and the Third Reich started organising a military plot against the Republic; 
- the political force behind the plot was fascism and the political regime which stemmed from the war was a fascist one;

- the war was in reality a struggle for national independence against the Third Reich and Italy's military intervention. The Spanish nation backed the legal government of the Second Spanish Republic;

- remaining silent about the existence of anarchists in Spain and revolutionary Comintern parties in the anti-Franco coalition;

- emphasising the leading role of the KPP and the Communist Party of France in recruiting Polish volunteers;

- remaining silent about the left's atrocities against the Church and clergy;

- emphasising the fact that the Second Polish Republic's government deprived the Dąbrowszczacy of their Polish citizenship;

- the United States actively cooperated with Franco's people during the war and during their dictatorship (Opioła, 2016, p. 185-189).

\section{SPANISH CIVIL WAR IN THE POLISH PRESS AFTER 1989}

The process of political change that started in the spring of 1989 enabled people to freely express their opinions in the mass media, and also made it possible for political minorities to be heard. As the capitalist media market emerged and political options crystallised, it turned out that there are, in contrast to previous periods of time, more than two or three narratives concerning the Spanish Civil War. There are currently many social and political circles that regard the war in a different way: the Catholic Church, descendants of the Dąbrowszczacy, liberal Catholics, the new left, traditionalists, liberal conservatives, and others. Any attempt at categorising them is often impossible, because they alter with time. One cannot attribute one idea/opinion with certain political groups. Despite this, a simplified style concerning the war is still present in present day journalism, which depicts the war as a struggle between two ideas and has a polemical character. The general tendency is, if some commentators trying to see the war from the point of view, for example, of humanism, the tragedy of individuals, or academic disciplines, and seeing it as a multi-layered problem, are tagged by any doctrinal-thinking adversaries, most often as the left, because in this discourse the right gained the early ground.

Still, among those participating in the discourse are groups characterised by a consistent attitude towards the Spanish Civil War, expressed in journalism as an element of political interest realisation. For the needs of this article they will be called 'the right', 'the central', and 'the left' camps on the stipulation that these names are just conventional and relate to attitudes of the Spanish Civil War only. The history of the war is an important element of these groups' identities, for not only do they often appeal to it, but also see the debate around it as an ideological discourse, something more important than an academic dispute over facts. In the context of political meaning of the war, adversaries only agree on one point - the war has a 
great myth-creating potential; however, each side of the argument accuses the other of mythologization of history, treating its own version as the true one. In the committed journalism, Krzysztof Lubczyński, in the social democratic Trybuna, writes about the 'falsified myth' of the war (Lubczyński, 2007), and Adam Wielomski, in the conservative Najwyższy Czas! about a seventy-year-long myth (Wielomski, 2006), although each of them believes the myth to be the other's version of events.

Is there, therefore, any space to distinguish the third kind of discourse, whose representatives I have called the central camp? Certainly there is, although right-wing journalism treats the remaining discourses (left-wing and central) concerning the war as basically the same, as they were antagonistic towards the Catholic, right-wing version. At the same time it accuses authors representing other points of view of having a liking for communism, even Stalinism. "We are witnessing a left-wing intrusive usurpation of the all-world intellectual discourse. It manifested itself, among others, by a brutal moral blackmail, according to which each conservative, right-wing, anticommunist phenomenon was labelled as "Hitlerism" - says Marek Jan Chodakiewicz (2003). "A one-sided picture of Spain during the war and almost 40-year-long administration of Franco, the picture being the product of zealous measures of communist propaganda and the unforgivable ignorance of the enlightened, a falsified one, is a classic example of the stereotype, which took place of the vibrant (...) truth. It was imposed on the collective awareness and lingers until the present day" - wrote Tomasz Burek (2007) in the bi-monthly Arcana. "Today's Franco's image in Poland is still the one established during communist times, the image of a fascist and criminal" - remarked Marcin Wolski in Gazeta Polska (2007).

Such allegations cannot be agreed with. The central camp's point of view should be rather treated as conservation of the pre-war newspapers' discourse: Robotnik and Wiadomości Literackie, at the same time upholding the ideals of personalism and liberalism. One characteristic feature of the centre groups' attitudes is seeing the war as a complex and tragic conflict. From this point of view it was impossible to opt for one of the parties. These groups' journalists would not agree to relativize crimes committed by both sides of the conflict, and they are usually far from seeing the conflict as the struggle of two totalitarian systems. They often refer to Ksawery Pruszyński’s and George Orwell's texts, but also to Georges Bernanos and Simone Weil's ones (Bernanos, 1998; Orwell, 2006; Pruszyński, 1937; Weil, 1998). Cezary Michalski, a well-known Polish journalist, sees the Spanish conflict from the centrist position as one of the left founding myths, ritualised by it with bias and similarly demystified by the right (Michalski, 1999). Remembrance of the Spanish Civil War was preserved through generations of People's Poland and was stained with totalitarian propaganda a lot less than right-wing authors thought. Analysis of the journalism shows that it was the right-wing propaganda that won the battle for post-1989 Polish public opinion concerning the war.

Left-wing journalism, on the other hand, partly freed itself of the propaganda influence of the Polska Rzeczpospolita Ludowa (PRL) era, although it still duplicated some of the myths, for example, those treating the war as a prelude to the 
Second World War and a training ground for Hitler and Mussolini, which present themselves as the new paradigm of the Spanish Civil War (Ikonowicz, 2006; Wielgosz, 2006). At the same time there is a traditional, left-wing, anti-fascist paradigm, which takes a form very similar to that from the PRL years. The reactionary groups of scheming generals are sometimes referred to in the left-wing media as 'Franco's fascists', 'fascist nationalists', or 'fascist falangists' (Lubczyński, 2007).

The debate on the Spanish Civil War emerges in the Polish media from time to time and is not always connected with celebrating anniversaries. One can see periods when the media devotes a lot of time and space to this. The wealthiest time regarding the presence of journalism concerning the war started in 2005. There are many factors behind this, of which the most important is the introduction of anti-communist political use of history by Law and Justice (PiS), where coming to terms with the history of the Dąbrowszczacy and the war itself is quite an important aspect. The issue of the Dąbrowszczacy's moral responsibility for combatant's crimes and depriving them of their combatant entitlements has been raised twice so far. The first debate on this started as early as 1990 and lasted until 1997; it was also touched upon again in 2006-2007. It should also be admitted that since the Third Polish Republic was founded, the leftist influence on the media has diminished. More and more newspapers and magazines have been closed, some others still exist, but their circulation figures are way below those of the mainstream or rightist press.

"One group within the Polish right, the one having the closest ties to nationalism and clericalism, sees something worth following in general Franco's policies (...) praising his actions and agreeing that one is allowed to kill his opponents in order to force respect and obedience, stemming from the values of the right" says Jorge Ruiz Lardizabal (2008), a Spanish news agency EFE correspondent in Poland. Which arguments make General Franco the saviour of the Polish right? Adam Wielomski, a historian and conservative journalist, saw a few fundamental advantages of the political system created by the dictator: stabilising the political situation in Spain for 40 years, defending the country from the possibility of far left rule, not taking part in the Second World War, balancing between the two groups fighting in the Second World War, and the economic liberalisation of the 1950s and 1960s (Wielomski, 2006). To back up this view, it seems that much was done by Stefan Kisielewski, the right's oracle in many fields, who spoke of his warm feelings towards the Spanish dictator (Kisielewski, 1996, p. 383). The Polish right generally associates the Spanish Civil War with the conflict between the two great worldview concepts, accepting the paradigm of the crusade against communism in order to defend Catholicism. Right-wing journalists very often emphasise that the war was the first win over communism in history (Martín Rubio, 2006, p. 27). This simple, one-sided understanding of the war presented by the Polish right is often created by journalists who do not possess proper historical expertise. Thus, articles aiming at becoming meticulously given evidence are not free of factual errors. A similar set of objections was articulated in the reviews of Marek Jan Chodakiewicz's book about 
the war published in 1997 (Chodakiewicz, 1997). Paweł Machcewicz (a historian and political scientist) accused the author of going in for journalism, not sticking to the facts, and "by all means legitimately undermining the leftist myths, substitutes them with different ones coming from the ideologically opposite stands" (Machcewicz, 1997). As Chodakiewicz understood them, the attitudes towards the Spanish Civil War in post-1989 Poland (up to 1997) were down to supporters of the PRL and the left-wing youth movements on one side and anti-communists on the other. $\mathrm{He}$ rejected the possibility of neutral attitudes within this area, although Machcewicz tried to prove that such attitudes exist and are natural.

Stefan Niesiołowski, previously a Solidarity Electoral Action (AWS) and currently Civic Platform (PO) MP, reacted to Machcewicz's review: "The Spanish Civil War is fascinating because the idea of justice was the winner there; the communists did not succeed in forcing The Gulag Archipelago onto the catholic nation" - he wrote in Gazeta Wyborcza, accusing Machcewicz of using argumentative means belonging to the PRL era (Niesiołowski, 1998). Niesiołowski reminded that in 1990 he supported taking veteran status away from the Dąbrowszcacy and that his stance had not altered, which is why he stood by Chodakiewicz on this. In this way, therefore, a review of a historical text started a political debate, which consisted of two distinct sides. The dispute in Gazeta Wyborcza was ended by additional explanations by Stefan Niesiołowski and Paweł Machcewicz.

For some on the right wing of the Polish political spectrum, General Francisco Franco has been a positive character, which seems to be of meaning to the position of Poland in international relations. In Wprost, Paweł Skibiński, a historian and right-wing journalist, enumerated the advantages of the Spanish dictator - being friendly towards the Polish independence camp in the PRL, saving Jews from the Holocaust, and entering into diplomatic relations with the Polish government-inexile. In his opinion, the Spanish Civil War was fuelled mainly by Moscow and the Comintern (Skibiński, 2002). A set of similar views were stated in the now defunct Ozon magazine, where he defended the Polish MEP Maciej Giertych in the wake of an incident that he triggered in the European Parliament (2006). In July 2006, Maciej Giertych (son of Jędrzej Giertych, the leader of the pre-war nationalists, who in 1936 was a correspondent in Spain), an MEP for the right-wing The League of Polish Families, gave a speech on the 70th anniversary of General Franco's coup. "Due to General Franco's actions, the communist attack on Catholic Spain was not successful" - said Giertych (Przemówienie..., 2006). "Maciej Giertych liked generals, who lead nations by harsh methods. In December 1981 he praised Jaruzelski for introducing martial law. (...) The Giertychs (Maciej Giertych and his son - Roman, who, at that time, acted as a deputy prime minister and the minister of education of Poland) would like to see Polish history in black-and-white, with themselves always on the side of the white" - replied Jarosław Kurski, a Gazeta Wyborcza journalist (2006). Polish MEPs were outraged by Giertych's comments, saying, amongst other things, that praising fascism included in a public speech is 
harmful to the way Poland was seen internationally (Oświadczenie..., 2006). The diplomatic and political row with Francoism in the background caused by Giertych became the reason to refresh - on the 70th anniversary - the Polish memory concerning the history of the Spanish Civil War, and at the same time the memory was politically instrumentalized. Both sides - Giertych, calling the supporters of Spanish Republic 'communists', and the Polish MEPs, labelling francoism as 'fascism' - manipulated, using these 'myths' as propaganda tools.

At the time of the debate on the political use of Spanish history, there was a discussion going on in the right-wing media on Spanish Catholicism. The issue was important for the right because there are many politicised phenomena in it: the engagement of Spanish clergy into the war and Franco's regime, John Paul II's participation in beatification processes of Spanish martyrs, confrontation with a view that Spain is a Catholic country, and, finally, the reaction to Zapatero's anticlerical and modernist policies. Polish Catholic groups are divided as to the above-mentioned issues, although all of them treat Spanish Catholicism as a 'problem' (Skibiński, 2006b, p. 23-24). There are different opinions concerning the Spanish clergy's attitude to Francoism: ranging from critical opinions (among others archbishop Józef Życiński 2006); through attempts at excusing it with the political interest: "It was a natural defensive stance built on the connection with the nationalists", wrote Marta Zając in Tygodnik Powszechny (2003); to utterances full of acceptance towards an alliance of throne and altar (Bartnik, 2008; Małecki, 2009). The tone stemming from Catholic journalism is often very similar to the one from before the war. This tone is as emotional as the pre-war one, and conspiracy thinking usual, with the exception of the Jew-masonic conspiracy being replaced by the atheistic one (see for example Bartnik, 2008).

One subject that has been touched upon most often - apart from attitudes towards Francoism - was the attitude towards the Dąbrowszczacy. In the 1990s, when right-wing coalitions ruled Poland, there were several attempts at taking veteran privileges away from Polish veterans of the Spanish Civil War. The anticommunist right perceived, and still does perceive veterans as criminals, just like those who unleashed the Stalinist machine of terror. The Dąbrowszczacy were defended not only by the old establishment, but also by the left-wing democratic opposition, some right-wing journalists and historians, and families and friends of the Dąbrowszczacy. One of the first protests against depriving the Dąbrowszczacy of their veteran status was Michał Komar's, a former Dąbrowszczak's son, a screenwriter and film critic, open letter to a newspaper. He wrote that these veterans are a part of the 'noble myth' that within the ranks of the International Brigades, apart from communists, there were socialists, and various kinds of democrats, Christian ones too (Komar, 1990). The next time depriving the Dąbrowszczacy of their veteran status was upon them was in 1993. The parliamentary committee concluded its proceedings on the parliamentary act in the latter part of 1994 and again the Dąbrowszczacy were not deprived of their status. In 1995 the veterans' privileges act 
was vetoed by then president Lech Wałęsa, who did not want to agree to formally treat the Dąbrowszczacy as veterans (Lipiński, 1997).

This debate came back to light in 2006 as one of PiS' elements of the politics of memory. This time, the newspaper debate had even stronger ideological overtones, as potentially depriving the Dąbrowszczacy of their veteran status was a matter for only the few of them still alive.

On March 30th, the leftist daily Trybuna published a long article depicting the Dąbrowszczacy's fortunes. The author - Piotr Skura - called the PiS law-making initiative 'a repressive idea of the IV RP rulers', stating that the Dąbrowszczacy's 'crime' was "binding themselves for the duration of the war with the leftist underground movement, and after the war - creation of the new order and rebuilding the homeland from ruins" (Skura, 2007). At the very same time, Gazeta Wyborcza informed about the Senate of Spain protest against the Polish parliamentary act concerning depriving Polish veterans of the war (mas, 2007).

The most important event, which triggered the long exchange of publications on the matter, was the Gazeta Wyborcza article of April 25th, titled Apel Antygony. It was an open letter on the Dąbrowszczacy written by Barbara Toruńczyk, daughter of Henryk Toruńczyk - the commander of the International Brigades division in 1939. It was a protest against erasing the Dąbrowszczacy from the collective memory and destroying their good name. The letter was signed by a few hundred people, descendants of Polish fighters in the war, and many public personalities: philosopher Leszek Kołakowski, historian Krzysztof Pomian, and Marek Edelman (the last leader of the Ghetto uprising). The letter expressed outrage at forcing on MPs "their own vision of history, coupled with disavowing defenceless seniors which shatters the meaning of their lives into pieces" (Apel Antygony, 2007). Moreover, the letter reminded that for many people born after 1945, the Spanish Civil War acted as a model for "pursuing freedom within post-Yalta Europe filled with the ice of totalitarianism and the Cold War" (ibid.). It is worth mentioning that the Spanish Republican government in exile accepted the Yalta system after 1945, contrary to anticommunist Franco's regime (see Kaczorowski, 2014). The letter was re-published by the Madrid daily El País (May 29th) and Zeszyty Literackie (no. 2/2007).

The letter triggered a wide debate in leading Polish newspapers, in which a few dozen people participated. Right-wing journalists polemicised with the content of the letter using the same arguments that they had used previously. "Crimes against prisoners of war, extermination of the clergy, executions of teachers, lawyers, clerks and other "plutocrats" - such were the heroic deeds of the revolutionary Spanish people, whom the Gazeta Wyborcza letters' authors try to present as worth-following fighters for a noble cause" - wrote Rafał Ziemkiewicz, a popular right-wing journalist, in Rzeczpospolita (2007). A fortnight later in the same newspaper, historian Piotr Gontarczyk called the Dąbrowszczacy "faithful Stalin's soldiers ready to follow all his orders (...) riders of the communist apocalypse" (Gontarczyk, 2007). The author accused them indirectly of the extermination of the Spanish clergy and 
destroying the Church in this country. Left-wing Krytyka Polityczna circles defended the Dąbrowszczacy by publishing an open letter on the 70th anniversary of the bombing of Guernica. "Fascism will not survive. NO PASARAN!" - was the highlight of the letter (Faszyzm nie przejdzie, 2007).

\section{CONCLUSIONS}

The analysis of contemporary discourses concerning the Spanish civil war shows that, for the struggle for symbolic power, the analysed topic matters. The actors of the discourse are not only historians and descendants of Polish volunteers, but also important political figures (president, deputies, MEPs, clergy). It is also evident, that the history of the Spanish Civil War was used as a propaganda tool, both as a political myth for right and left-wing politicians (antifascist and anti-communist references in the narratives) and as a rhetoric figure. It is worth mentioning that both of these clichés, are still very strongly exposed in Polish historical and political debate. All historical books concerning the war, translated and edited in Poland, must be labelled in the media as 'written by' either a leftist, liberal, or right-wing historian. This is a process of the ideologisation of history. However, the Spanish Civil War and its key contexts for Polish remembrance are no longer crucial to the current debate. It is vanishing not because the trauma has passed, the ideological reconciliation occurred, or the compromise settled on - with the years that have gone by, there are a number of people for whom the war carries features of an important myth, an element forming civic ethos.

When it comes to the second research problem, the comparison of the three analysed periods shows that there is no chronological succession of the discourses. The main findings from the analysis of the period 1945-1989, shows the process of negation prior discourses. Again, in 1989, the former narrative was denied. We can also observe the return to the 1936-1939 narratives. The liberal narrative should be treated as conservation of the pre-war newspapers' discourse: Robotnik and Wiadomości Literackie. The characteristic feature is seeing the war as a complex and tragic conflict. Left-wing journalism, on the other hand, partly freed itself of the propaganda influence of the 1945-1989 era, although it still duplicated some of the myths. Analysis also shows that the right-wing narrative won the battle for post-1989 Polish public opinion concerning the war.

\section{REFERENCES}

Ajzner, S. (1968). Polska a wojna domowa w Hiszpanii 1936-1939. Warszawa: Państwowe Wydawnictwo Naukowe.

Apel Antygony (2007). List otwarty w sprawie Dąbrowszczaków. Gazeta Wyborcza, 25.04.2007.

Barthes, R. (1970). Mit i znak Eseje. Warszawa: Państwowy Instytut Wydawniczy.

Bartnik, C. (2008). Skąd taka nienawiść do katolicyzmu? Nasz Dziennik, 1.06.2008.

Bartoszewicz, J. (1937). Czerwone niebezpieczeństwo. Myśl Narodowa, 45. 
Bednarczuk, M. (2008). Obraz hiszpańskiej wojny domowej lat 1936-1939 w piśmiennictwie polskim. Toruń: Wydawnictwo Adam Marszałek.

Beevor, A. (2009). Walka o Hiszpanię 1936-1939. Kraków: Wydawnictwo Znak.

Bernanos, G. (1998). Cmentarzyska pod księżycem. Zeszyty Literackie, 63, pp. 63-72.

Boski, R. (1936.07.30). Międzynarodówka sprzedawczyków. Robotnik.

Bourdieu, P., Thompson, J.B. (1991). Language and symbolic power. Harvard University Press.

Bron, M. (ed.) (1967). Polacy w wojnie hiszpańskiej (1936-1939). Warszawa: Wydawnictwo MON.

Burek, T. (2007). W Hiszpanii białej. Arcana, 6.

Chodakiewicz, M.J. (1997). Zagrabiona pamięć. Wojna w Hiszpanii 1936-39. Warszawa: Fronda.

Chodakiewicz, M.J. (2003). Biali internacjonaliści. Arcana, 6.

Cieński, M. (1990). Literatura polska wobec wojny domowej w Hiszpanii. Wybrane zagadnienia. Prace Literackie, vol. XXVIII.

Czajka, M. (1980). Polska opinia publiczna wobec wojny domowej w Hiszpanii 1936-1937. Przegląd Historyczny, LXXI (2).

Eliade, M. (1999). Mity, sny i misteria. Warszawa: Wydawnictwo KR.

Fajans, R. (1937). Hiszpania 1936: (z wrażeń korespondenta wojennego). Warszawa: Towarzystwo Wydawnicze Rój.

Faszyzm nie przejdzie (2007). Rzeczpospolita, 07.05.2007.

Francois, E. (2010). Jeszcze raz o historii pamięci. Kultura Współczesna, 1.

Friszke, A. (1989). O kształt niepodległej. Warszawa: Biblioteka Więzi.

Giertych, J. (1937). Hiszpania bohaterska. Warszawa: Ossolineum.

Glondys, O. (2014). Entre la propaganda y la verdad: cambios del paradigma en el discurso polaco sobre la Guerra Civil española. Studia Historica. Historia Contemporánea, 32, pp. 501-517.

Gola, B. (1995). Upadek II Republiki w Hiszpanii. Narastanie konfliktu destruktywnego. In: Ryszka, F., (ed.), Historia Idee Polityka. Księga dedykowana Profesorowi Janowi Baszkiewiczowi. Warszawa: Wydawnictwo Uniwersytetu Warszawskiego.

Gontarczyk, P. (2007). Dąbrowszczacy — żołnierze Stalina. Rzeczpospolita, 07.05.2007.

Górecki, J. (1936). Strona czwarta. Dziennik Popularny, 21.10.1936.

Habielski, R. (2009). Polityczna historia mediów w Polsce w XX wieku. Warszawa: Wydawnictwa Akademickie i Profesjonalne.

Hertz, A. (2003). Żydzi w kulturze polskiej. Warszawa: Biblioteka Więzi.

Ikonowicz, M. (2006). Pamięć bez wendety. Przeglad, 10.09.2006.

Jackson, G. (1999). La República española y la guerra civil, 1931-1939. Barcelona: Editorial Critica.

Judt, T. (2008a). Powojnie. Historia Europy od roku 1945. Poznań: Wydawnictwo Rebis.

Judt, T. (2008b). Reappraisals: Reflections on the Forgotten Twentieth Century. New York: The Penguin Press.

Judt, T. (2011). Źle ma się kraj. Rozprawa o naszych współczesnych bolączkach. Wołowiec: Wydawnictwo Czarne.

Kaczorowski, B. (2014). Churchill i Franco. Hiszpania w polityce Wielkiej Brytanii w okresie drugiej wojny światowej. Warszawa: Wydawnictwo DiG.

Kieniewicz, J. (2001). Hiszpania w zwierciadle polskim. Gdańsk: Novus Orbis.

Kisielewski, S. (1996). Dzienniki. Warszawa: Iskry.

Komar, M. (2014). Ciemna strona mocy (interview with Michał Komar). Tygodnik Powszechny, 3.

Komar, M. (1990). Dąbrowszczacy — cząstka szlachetnego mitu. Gazeta Wyborcza, 10.10.1990.

Komarnicki, W. (1937). Totalizm a Polska. Myśl Narodowa, 49.

Korfanty, W. (1936). Moralny Czerwony Krzyż w Europie. Polonia, 04.10.1936.

Kotowski, A.S. (2006). Narodowa demokracja wobec nazizmu i Trzeciej Rzeszy. Toruń: Wydawnictwo Adam Marszałek.

Kurski, J. (2006). Spóźniona odwaga Giertychów. Gazeta Wyborcza, 05.07.2006.

Leith, D., Myerson, G. (1989). The Power of Address. Explorations in Rhetoric. London: Routledge. 
Lipiński, P. (1997). Dynamit i cześć. Gazeta Wyborcza, 4.01.1997.

Lubczyński, K. (2007). Kres zakłamanego mitu. Trybuna, 24.11.2007.

Macała, J. (1997). “Wojna chrześcijaństwa z barbarzyństwem”. Polska prasa katolicka wobec wojny domowej w Hiszpanii 1936-1939. Studia nad Faszyzmem i Zbrodniami Hitlerowskimi, XX.

Machcewicz, P. (1997). Wojna hiszpańska trwa. Gazeta Wyborcza, 26.11.1997.

Maciejewski, M. (1998). Hiszpański faszyzm i frankizm w polskiej literaturze politycznej i naukowej (1936-1997). Studia nad Faszyzmem i Zbrodniami Hitlerowskimi, XXI.

Małecki, L. (2009). Hiszpańska wojna domowa 1936-39. Niedziela, 26.04.2009.

Martín Rubio, A.D. (2006). Rzeka krwi. Christianitas, 26.

mas (2007). Madryt broni Dąbrowszczaków przed polskim rządem. Gazeta Wyborcza, 25.03.2007.

Michalski, C. (1999). Nowe rozważania o wojnie domowej. Czas kultury, 4-5.

Nałęcz, D. (ed.) (1993). Nie szabla lecz piórem: batalie publicystyczne w II Rzeczpospolitej. Warszawa: Wydawnictwo IBL PAN.

Niedziałkowski, M. (1936). Francja i Hiszpania. Dwa doświadczenia. Robotnik, 23.07.1936.

Niesiołowski, S. (1998). Rachunek zbrodni, Gazeta Wyborcza, 16.01.1998.

Opioła, W. (2010a). Polska prasa prawicowa wobec interwencji Włoch i III Rzeszy w Hiszpanii 19361939. Studia nad Faszyzmem i Zbrodniami Hitlerowskimi, XXXII.

Opioła, W. (2010b). Stanowisko polskiej prasy katolickiej wobec wojny domowej w Hiszpanii 19361939. Analiza dyskursu medialnego. Media-Kultura-Społeczeństwo, 5.

Opioła, W. (2013). O szkodliwości generalizowania w historii. Przypadek dąbrowszczaków. In: Minkner, K., Rubisz, L. (ed.), Antynomie polityczności. Artykuty, eseje i szkice dedykowane Profesor Barbarze Goli. Opole: Wydawnictwo Uniwersytetu Opolskiego.

Opioła, W. (2016). Hiszpańska wojna domowa w polskich dyskursach politycznych. Analiza publicystyki 1936-2015. Opole: Wydawnictwo Uniwersytetu Opolskiego.

Orwell, G. (2006). Hołd dla Katalonii i inne teksty o hiszpańskiej wojnie domowej, Warszawa: Oficyna Literacka.

Oświadczenie... (2006). Oświadczenie polskich eurodeputowanych. Gazeta Wyborcza, 5.07.2006.

Polscy robotnicy... (1936). Polscy robotnicy walczą w Hiszpanii. Czerwony Sztandar, 25.11.1936.

Ponure cienie... (1937). Ponure cienie hiszpańskiego problemu. Czas, 10.01.1937.

Preston, P. (2011). El holocausto español. Madrid: Debate.

Pruszyński, K. (1936). Żywi i umarli. Wiadomości Literackie, 13.12.1936.

Pruszyński, K. (1937). W czerwonej Hiszpanii. Warszawa: Towarzystwo Wydawnicze Rój.

Przemówienie... (2006). Przemówienie Macieja Giertycha 4 lipca 2006 podczas debaty w Parlamencie Europejskim w 70. rocznicę zamachu stanu generała Franco. Gazeta Wyborcza, 05.07.2006.

Ruiz Lardizabal, J. (2008). Zapatero nie przyda się polskiej lewicy. Gazeta Wyborcza, 19.06.2008.

Sawicki, P. (2008). Polska hagiografia generała Franco. In: El cambio de la imagen mutua de Polonia y España desde la transición. Zmiana wzajemnego obrazu Hiszpanii i Polski od czasu przejścia do demokracji. Warszawa: Instytut Cervantesa and IH PAN.

Skibiński, P. (2002). Dyktator demokracji. Wprost, 16.06.2002.

Skibiński, P. (2006a). Franco - pogromca komunizmu. Ozon, 26.07.2006.

Skibiński, P. (2006b). O hiszpańskiej wojnie domowej, Christianitas, 26.

Skura, P. (2007). Za waszą wolność i naszą. Trybuna, 20.03.2007.

Słonimski, A. (1936a). Kronika tygodniowa. Wiadomości Literackie, 16.08.1936.

Słonimski, A. (1936b). Kronika tygodniowa. Wiadomości Literackie, 15.11.1936.

Southworth, H.R. (1977). Guernica! Guernica! A Study of Journalism, Diplomacy, Propaganda and History. Berkeley, Los Angeles, London: University of California Press.

Southworth, H.R. (2002). Conspiracy and the Spanish Civil War, The Brainwashing of Francisco Franco. London, New York: Taylor \& Francis.

Sprawozdanie... (1938). Sprawozdanie i rezultaty obrad jury nagrody „Wiadomości Literackich” za najwybitniejszą książkę polską 1937 r. Wiadomości Literackie, 13.03.1938. 
Szpociński, A. (2010). Współczesna kultura historyczna. Kultura Współczesna, 1.

Thomas, H. (1995). La guerra civil española. Barcelona: Grijalbo Mondadori.

Toruńczyk, R. (1965). O składzie osobowym polskich ochotników w Hiszpanii republikańskiej w latach 1936-1938. Z pola walki, 1.

W chwili... (1936). W chwili najstraszniejszego pożaru. List Pasterski Biskupów Rzeczypospolitej Polskiej z Jasnogórskiego Synodu Plenarnego. Przewodnik Katolicki, 20.09.1936.

Wasiutyński, B. (1936). Autorytet czy wolność? Kurier Poznański, 14.08.1936.

Wasiutyński, W. (1936). Wojny religijne już się zaczęły. Prosto z Mostu, 37.

Weil, S. (1998). List do Bernanosa, Zeszyty Literackie, 63, pp. 72-76.

Wielgosz, P. (2006). Polityka historyczna lewicy? Przeglad, 51-52.

Wielomski, A. (2006). 70 długich lat mitu. Najwyższy Czas!, 12.08.2006.

Wolski, M. (2007). Komu bił ten dzwon? Gazeta Polska, 25.04.2007.

Zając, M. (2003). Jeden Kościól, dwie Hiszpanie. Tygodnik Powszechny, 04.05.2003.

Ziemkiewicz, R. (2007). Dąbrowszczacy - żołnierze niesłusznej sprawy. Rzeczpospolita, 27.04.2007.

Życiński, J. (2006). Świadkowie Bożego Królestwa. List Metropolity Lubelskiego abp. Józefa Życińskiego na I Niedzielę Wielkiego Postu. Bishop’s epistle, Retrieved April 1, 2014 from http:// www.jozefzycinski.eu/index.php?option=com_content\&view=article\&id=99:list-metropolity-lubelskiego-na-i-niedziel-wielkiego-postu-2006-roku\&catid=1:lp\&Itemid=2. 